\title{
Influence of temperature and relative humidity on viability of coated seeds of chilli under stored conditions
}

\author{
S. Surya Kumari ${ }^{1}$, K.Umajyothi ${ }^{2}$, K.Giridhar $^{1}{ }^{1}$ T.Vijayalakshmi ${ }^{3}$, A. Rajani $^{3}$ \\ C.Venkata Ramana ${ }^{4}$, And L. Naram Naidu ${ }^{4}$ \\ ${ }^{l}$ All India Coordinated Research Project on Spices \\ ${ }^{2}$ College of Horticulture, Venkataramannagudem \\ ${ }^{3}$ All India Coordinated Research Project on Vegetable Crops \\ ${ }^{4}$ Chillies Improvement Scheme, Dr. Y.S.R. Horticultural University, Horticultural Research Station, Lam, \\ Guntur-522 034.
}

\begin{abstract}
The Seed is the primary investment for successful crop production that demands good germination to produce a vigorous seedling ensuring high yields. The chilli seed after extraction from pod is viable for shorter periods ranging from 8-10 months under ambient storage conditions. This hybrid chilli seed is the most critical input to the farmer and is available in the market after coating with polymer/fungicide. Weather parameters like temperature and relative humidity play a key role in maintaining the viability of chilli seed during open storage. Keeping this in view a study was initiated at YSRHU, HRS, Lam under AICRP on vegetable Crops during 2009-11 for a period of 20months with 5 periods of storage viz; 6months, 8months, 12 months, 16months and 20 months and 6 Seed Coatings i.e., polymer, imidacloprid, bavistin, polymer and imidacloprid, Polymer and bavistin, polymer with imidacloprid and bavistin and untreated seed as control. The meteorological data for the period under the study and its influence on seed viability parameters as \%germination, \%field emergence, \%mortality and speed of germination was recorded at different periods of storage. The seedling vigour indices were also studied as influenced by the temperature and relative humidity. During the period under study the mean maximum temperature ranged from 29.5 to $41.7^{\circ} \mathrm{C}$ and mean minimum temperature ranged from 16.1 to $27.9^{\circ} \mathrm{C}$ and the mean morning relative humidity ranged from 70.1 to 96.2 and the mean evening relative humidity ranged from 24.2 to 73.1 . There was gradual decrease in all the above viability parameters of chilli seed starting from 6months to 20months of ambient storage. Among the storage periods percent field emergence was within the acceptable limit (> 60\%) up to twelve months of storage. Among the different combinations of seed coatings with polymer and polymer with different plant protection chemicals the seed coated with polymer alone was viable and recorded field emergence $>60 \%$ up to 6months of storage under ambient conditions. Seed coated with plant protection chemicals alone or in combination with polymer lost its viability during storage before six months under ambient conditions. It can be inferred that under ambient conditions of storage the chill seed can be stored viable for 6months when coated with polymer alone and for 12 months without any seed coating.
\end{abstract}

Keywords: Relative humidity, Seed, Storage, Temperature, Variability, and Vigour.

\section{Introduction}

Chilli (Capsicum annum L.) is an important spice and vegetable crop of global importance valued for its colour, flavour and nutritional value (Berke et al., 2004). Under ambient conditions the chilli seeds with thin seed coat show rapid deterioration in the prevailing tropical to subtropical climate in India. (Umajyothi et al., 2008) To combat this situation in recent times the film coating techniques on the seeds are being studied. These film formulations consist of a mixture of polymer, plasticizer and colourants (Robani, 1994). These are commercially available as ready to use liquids or as dry powders (Ni 1997). The polymer film coating may act as a physical barrier, which has been reported to reduce the leaching of inhibitors from the seed coat and may restrict oxygen diffusion to the embryo (Vanangamudi et al., 2003) thus reducing the speed of deterioration. Seed coating with synthetic polymer (polykote) in combination with fungicides was a tool for quality hybrid rice seed storage and was effective against seed and soil borne pathogens (Pham Long Giang and Rame Gowda 2007). It is the immediate need to develop polymer based seed coats that prevent moisture entry, fungus penetration and insect attack during storage (Jitendra Kumar et al., 2007). Hence in the present investigation efforts have been made to study the seed quality status of polymer coated chilli seed during storage in ambient conditions under the coastal environment of Andhra Pradesh with high temperature and high relative humidity. 


\section{Materials And Methods}

A storage experiment was carried out from 2009-11 at Dr. Y.S.R.H.U., HRS, Lam under AICRP on Vegetable crops. The harvested chilli seeds of the year 2008-09 were taken, cleaned, dried to 7\%moisture content and then treated with polymer coatings and stored in cloth bags for 20 months. The experiment was done in RBD with factorial concept with 35 treatment combinations with 5 periods of storage for study i.e., 6 months, 8months, 12 months, 16 months and 20months and 6 seed coatings with polymer $(10 \mathrm{mg} / 1 \mathrm{~kg}$ seed), Imidacloprid $(8 \mathrm{~g} / 1 \mathrm{~kg}$ seed), Bavistin $(1 \mathrm{~g} / \mathrm{kg}$ seed) and combination of polymer with Imidacloprid, Bavistin and untreated seeds as control.

The temperature and relative humidity for the period under study and its influence on seed viability was recorded at the specific periods of storage. The seed samples were drawn at specific periods of study and the observations were recorded on germination percentage (ISTA 1993) seedling length, vigour index (Abdul Baki and Anderson, 1973), field emergence, mortality and speed of germination. The data obtained from the experiment was subjected to statistical analysis (Panse and Sukhmate, 1985).

\section{Results And Discussion}

The safe storage conditions for short periods, from harvest to next planting season (1-9 months) are those in which the seed equilibrium moisture is lower than $14 \%$ for cereal seeds, $11 \%$ for oil seeds and $7-8 \%$ for most of the vegetable seeds. This means seed moisture in equilibrium with $50 \% \mathrm{RH}$ at $30^{\circ} \mathrm{c}$ or $60 \% \mathrm{RH}$ at $20^{\circ} \mathrm{c}$ (Delouche et al., 1973) or with $65 \% \mathrm{RH}$ at a temperature higher than $33^{\circ} \mathrm{c}$ for only few hours.

During the period under study the mean maximum temperature ranged from $29.5^{\circ} \mathrm{C}$ to $41.7^{\circ} \mathrm{C}$ and mean minimum temperature ranged from $16.1^{\circ} \mathrm{C}$ to $27.9^{\circ} \mathrm{C}$. The mean morning relative humidity ranged from 70.1 to $96.2 \%$ and the mean evening relative humidity from 24.2 to $73.1 \%$.

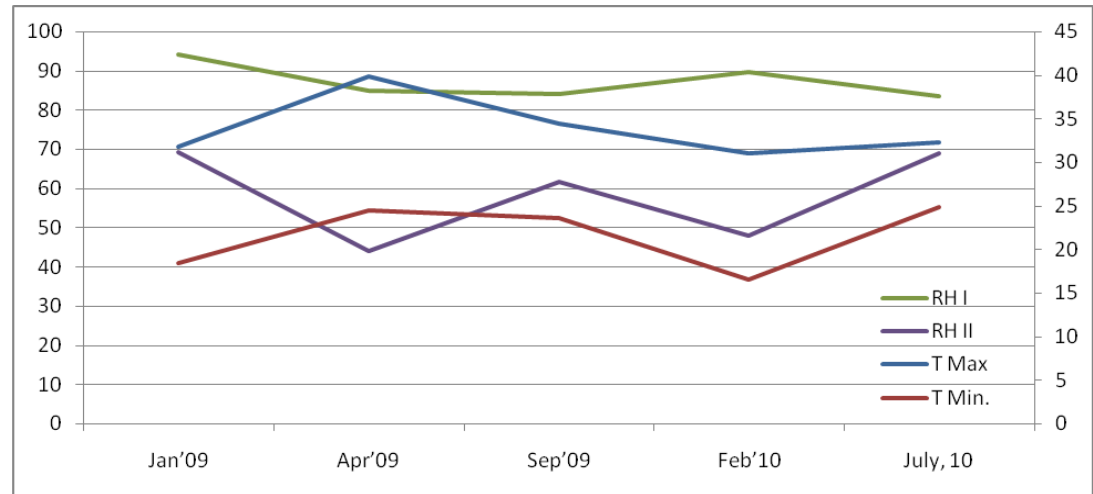

Figure 1: Temperature and Relative Humidity during the storage period

Under this prevailing climatic storage under high fluctuating temperatures and moisture levels, the seed being highly hygroscopic living material it absorbs moisture from air if it is stored in an environment where relative humidity is higher than seed moisture content.

There was gradual decrease in all the viability parameters of chilli seed i.e., from 92.29 to12\% in germination ,72.21 to3 \% in field emergence,31.9 to 1.04 in speed of germination,5.53to1.23 in SVR-Iand 669.21 to 40.87 in SVI-II starting from 6months to 20months period of ambient storage. Among the storage periods percentage field emergence was within the acceptable limit (> 60\%) up to twelve months of storage. The treatment decline over periods of storage for viability of chilli seed might be attributed due to storage in cloth bag where there was much fluctuation in seed moisture .It could be attributed to the hastened process of deterioration in the seed collected from the chilli kept at high temperatures and high humidity and stored in cloth bags. Similar results were reported in chilli by Doijode (1991) UmaJyothi et al., (2008) Barua et al., (2009). The decline in viability parameters of the seeds might be attributed to ageing effect, leading to depletion of food reserves and synthetic activity of embryo apart from death of seed because of fungal invasion, insect damage and storage conditions. 


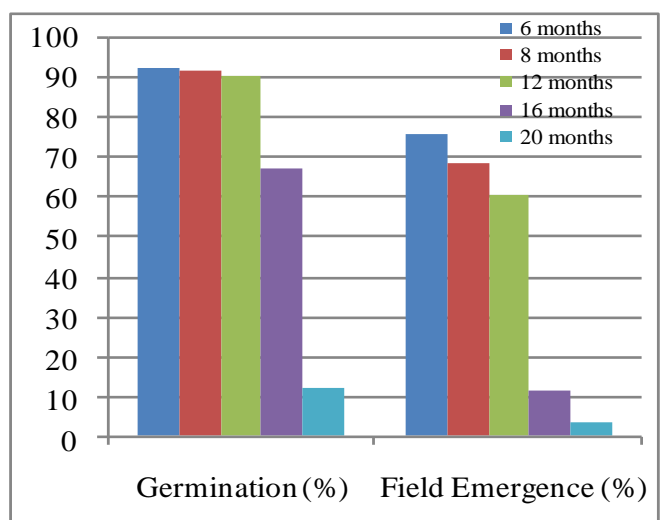

Figure 2: Germination and field emergence as influenced by periods of storage

The viability of chilli seed was significantly influenced by different combinations of seed coatings with polymer and polymer with different plant protection chemicals. Among the seed coatings treatments maximum seed germination $(78.32 \%)$, field emergence percentage (38.2\%) least mortality (15.23\%)higher vigour indices ( 3.32 and 474.3) were recorded in control i.e. untreated seed closely followed by the seed treated with polymer alone (T2) and significantly superior over other polymer treatments.
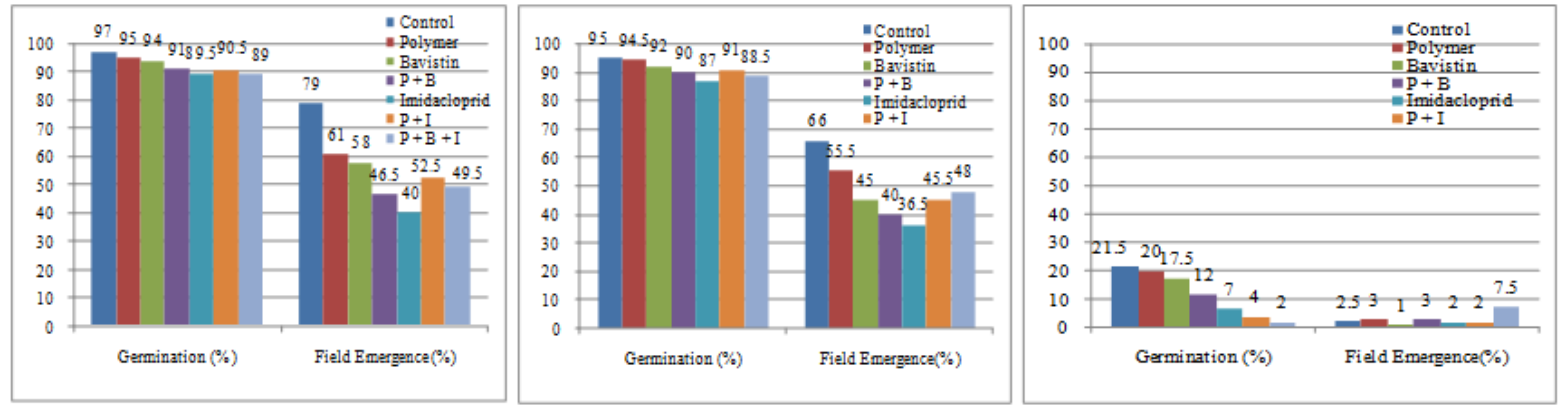

Figure 3: Germination and field emergence as affected by seed coatings at 6, 12 and 20 months after storage

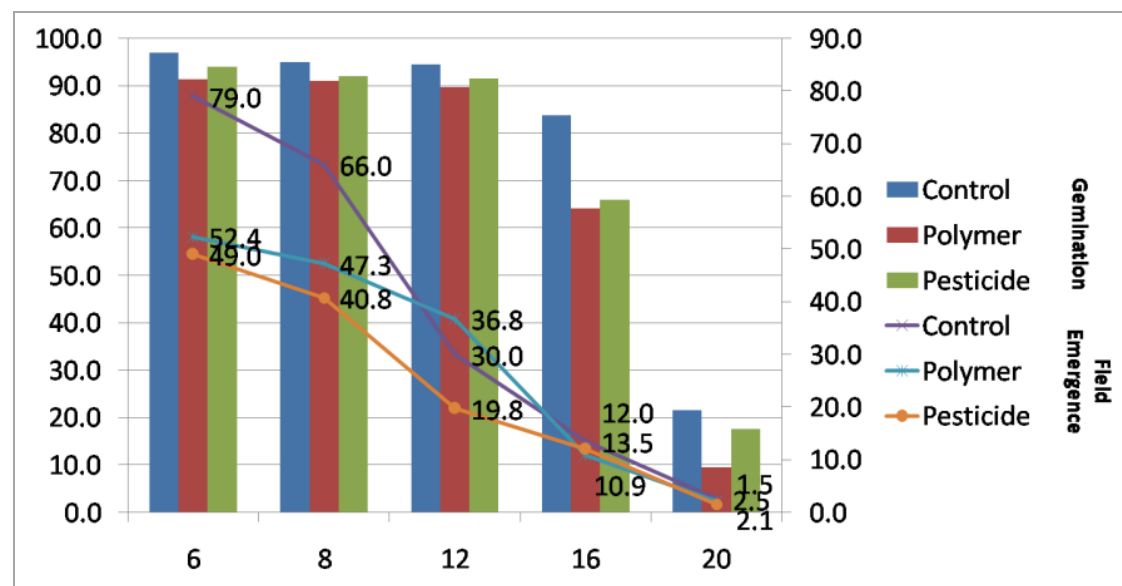

Figure 4: Germination and field emergence during storage period in Control (C), Polymer (P) and Pesticide coatings.

From the treatment interactions it was observed that the untreated chilli seed maintained its viability up to 12 months. However, among the treatments all the viability parameters were below the minimal standards with regard to field emergence, speed of germination and vigour indices after six months of storage. Similar results of decrease of viability parameters due to seed coating with dye, pelleting and polymer with increase in storage period was reported in cotton (Vijaykumar et al., 2007), Soya bean (Kurdikeri et al., 1996), hybrid Rice (Rettinassababady et al., 2012), Tomato (Shashibhaskar et al., 2012) and Chilli (Manjunatha et al., 2008). 


\section{Conclusion}

There was gradual decrease in all the seed viability characters of chilli over periods of storage starting from 6months to 20 months. Seed coated with plant protection chemicals alone or in combination with polymer lost its viability during storage before six months under ambient conditions. It can be inferred that under ambient conditions of storage the chill seed can be stored viable for 6months when coated with polymer alone and for 12 months without any seed coating.

\section{References}

[1]. Abdul-Baki, A. A. and Anderson, J. D. (1973). Vigour determination in soybean by multiple criteria. Crop Science 10: 31-34.

[2]. Barua, H., Rahman, M.M., and Masud, M.M. (2009). Effect of storage containers environment at different storage period on the quality of chilli seed. Int. J. Sustain. Crop Prod. 4(4): 28-32.

[3]. Berke, T, Black, L.L., Talekar, N.S., Wang, J.F., Griffike, P., Morris, R., 2004. Suggested cultural practices for chilli pepper AVRDC pub. \# 03-575. 8 p.

[4]. Delouche, J.C., Mathes, R. K., Dougherty, G.M. and Boyd, A.H. (1973). Storage of seeds in sub tropical and tropical regions. Seed Science and Technology, 1:671-700.

[5]. Doijode, S.D. (1991). Influence of seed position on seed storability and vigour during ambient storage of chilli (Capsicum annuum L) fruits. Capsicum Newsletter 10: 62-63

[6]. Harrington, J.F. (1972). Seed Storage and longevity. In: "Seed Biology" (ed. T. Kozlosky) New York: pp.142-145.

[7]. ISTA. (1993). International rules for seed testing. Seed Science and Technology 21 Supplement.

[8]. Jitendra Kumar, Nisark, Arun Kumar, M.B., Suresh Wali

[9]. a, Shakil, Rajendra Prasad and Parmer BS (2007). Development of polymeric seed coats for seed qualityenhancement of soyabean (Glycine max L.). Indian Journal of Agric. Sciences.,77(11):738-43.

[10]. Kurdikeri, M.B. Basavaraj, G.T. Hiremath, M.V. and S.C.Aswathanarayan. 1996. Storability of soyabean (Glycine max (L.) Merill) seed under ambient condition. Karnataka J. of Agric. Sci., 9: 552-554.

[11]. Manjunatha S.N., Ravi Hunje, N.K., B.S. Vyakaranahal and I.K. Kalappanavar. 2008. Effect of seed coating with polymer, fungicide and containers on seed quality of chilli during storage. Karnataka J. of Agric. Sci. 21 (2): 270-273.

[12]. Manjunatha, S.N., RaviHunje, B.S., Vyakararanhal, B.S. and Kalppanavar. (2008). Effect of seed coating with polymers and fungicides on seed qualityof chilli during storage. Seed Research., 36(1):42-46.

[13]. Ni, B.R. (1997). Seed coating ,film coating and pelleting. In seed industry and agricultural development, Chinese Association of Agricultural Sciences, DOA, Ministry of Agriculture, Beijing, China, Agriculture Press, pp. 737-747.

[14]. Panse, V.G. and Sukhatme, P.V. 1985. In: Statistical methods for Agricultural Workers, ICAR, New Delhi, pp. 327-340.

[15]. Pham Long Giang and Rame Gowda. 2007. Influence of seed coating with synthetic polymer and chemicals on seed quality and storability of hybrid rice (Oryza sativa L.). Omanrice, 15: 68-74.

[16]. Rettinassababady C., Ramanadane, T. and R. Renuka. 2012. Role of polymer coating on seed quality status of hybrid rice (Oryza sativa L.) during storage under coastal ecosystem. J. Biol. Chem. Research. Vol. 29, No. 2: 142-150.

[17]. Robani, H., (1994). Film coating in horticultural seed. Horticultural Technology. 4: 104-105.

[18]. Shashibhaskar, M.S., Vinutha, K.S., Nagabhushan, Vasudevan, S.N., and V. Ramanjinappa. 2012. Seed quality as influenced by seed pelleting and containers during storage in Tomato. Plant Archives, Vol. 12, No. 2, pp. 1101-1008.

[19]. Umajyothi, K., Surya Kumari, S., Venkata Reddy, P. and Ravi Sankar, C. Influence of storage temperatures and relative humidity with post-harvest chemical treatments on germination and vigour index of chilli cultivar LCA-334. 2008. Journal of Agrometeorology Vol. 10 (Special Issue 2008) - Part II: 431-435.

[20]. Vanangamudi, K., Srimathi, P., Natarajan, N. and Bhaskaran, M. 2003. Current scenario of seed coating polymer. In proc. of ICAR-Short course on seed hardening and pelleting technologies for rainfed/gardenland ecosystems, New Delhi. Pp. 80-200.

[21]. Vijaykumar Kunkur, K., Ravi Hunje, N.K. Biradar Patil and B.S. Vyakaranahal. 2007. Effect of seed coating with polymer, fungicide and insecticide on seed quality in cotton during storage. Karnataka J. Agric. Sci., 20 (1): 137-139. 
Table 1. Effect of seed coatings and periods of storage on seed viability parameters

\begin{tabular}{|c|c|c|c|c|c|c|}
\hline Treatments & Germination \% & $\begin{array}{c}\text { Field } \\
\text { Emergence \% }\end{array}$ & Mortality \% & $\begin{array}{c}\text { Speed of } \\
\text { germination }\end{array}$ & $\begin{array}{c}\text { Seedling } \\
\text { Vigour } \\
\text { Index-I }\end{array}$ & $\begin{array}{c}\text { Seedling } \\
\text { Vigour } \\
\text { Index-II }\end{array}$ \\
\hline \multicolumn{7}{|l|}{ Factor I : Storage Periods (S) } \\
\hline S1-6 months & $92.29(74.20)$ & $75.21(62.51)$ & $36.93(37.30)$ & 31.92 & 5.53 & 669.21 \\
\hline S2-8 months & $91.14(72.90)$ & $68.07(56.84)$ & $43.07(40.99)$ & 24.62 & 5.54 & 627.13 \\
\hline S3-12 months & $90.29(71.99)$ & $60.21(50.13)$ & $12.72(19.91)$ & 8.26 & 3.98 & 566.21 \\
\hline S4-16 months & $66.89(55.21)$ & $11.57(19.39)$ & $10.87(18.79)$ & 2.16 & 2.13 & 583.83 \\
\hline S5-20 months & $12.00(19.10)$ & $3.0(9.4)$ & $13.81(12.56)$ & 1.04 & 1.23 & 40.87 \\
\hline CD (5\%) & 1.2 & 1.25 & 1.17 & 0.99 & 0.14 & 4.81 \\
\hline \multicolumn{7}{|l|}{ Factor II: Seed Coatings (T) } \\
\hline T1-Control & $78.35(65.49)$ & $38.2(36.16)$ & $15.3(19.02)$ & 14.61 & 3.32 & 474.3 \\
\hline T2-Polymer & $76.80(63.81)$ & $32.29(33.08)$ & $25.28(29.43)$ & 16.18 & 3.55 & 475.0 \\
\hline T3-Bavistin 1\% & $72.20(60.29)$ & $30.0(30.92)$ & $16.56(20.44)$ & 11.35 & 4.34 & 445.9 \\
\hline T4-Polymer-Bavistin1\% & $69.80(58.04)$ & $26.7(29.18)$ & $24.44(25.51)$ & 11.76 & 3.55 & 544.3 \\
\hline T5-Imidacloprid 1\% & $66.55(55.25)$ & $19.2(23.49)$ & $25.37(26.73)$ & 11.32 & 3.39 & 432.1 \\
\hline $\begin{array}{l}\text { T6 -Polymer - Imidacloprid } \\
1 \%\end{array}$ & $66.05(55.01)$ & $29.2(30.16)$ & $21.58(24.66)$ & 14.72 & 3.55 & 481.0 \\
\hline $\begin{array}{l}\text { T7 - Polymer - Imidacloprid } \\
1 \% \\
\quad \text { - Bavistin } 1 \%\end{array}$ & $63.90(52.84)$ & $32.1(32.96)$ & $35.81(35.58)$ & 15.21 & 3.92 & 559.7 \\
\hline CD (5\%) & 1.41 & 1.48 & 0.91 & 1.17 & 0.17 & 5.69 \\
\hline
\end{tabular}

Table 2: Interaction of periods of storage and seed coatings on seed viability parameters

\begin{tabular}{|c|c|c|c|c|c|c|}
\hline Treatments & $\begin{array}{c}\text { Germination } \\
\%\end{array}$ & $\begin{array}{c}\text { Field } \\
\text { Emergence \% }\end{array}$ & Mortality \% & $\begin{array}{c}\text { Speed of } \\
\text { germination }\end{array}$ & $\begin{array}{c}\text { Seedling } \\
\text { Vigour } \\
\text { Index-I }\end{array}$ & $\begin{array}{c}\text { Seedling } \\
\text { Vigour } \\
\text { Index-II }\end{array}$ \\
\hline S1T1 & $97.0(80.1)$ & $79.0(62.71)$ & $26.0(30.63)$ & 36.1 & 5.6 & 459.0 \\
\hline S1T2 & $95.0(77.1)$ & $61.0(51.34)$ & $36.0(36.85)$ & 37.9 & 5.1 & 571.6 \\
\hline S1T3 & $94.0(75.8)$ & $58.0(49.58)$ & $47.0(43.26)$ & 26.6 & 6.5 & 537.6 \\
\hline S1T4 & $91.0(72.5)$ & $46.5(42.98)$ & $28.5(32.25)$ & 24.1 & 5.0 & 580.2 \\
\hline S1T5 & $89.5(71.1)$ & $40.0(39.21)$ & $47.0(43.26)$ & 30.1 & 5.3 & 508.1 \\
\hline S1T6 & $90.5(72.0)$ & $52.5(46.41)$ & $34.5(35.96)$ & 34.7 & 5.6 & 511.5 \\
\hline S1T7 & $89.0(70.6)$ & $49.5(44.70)$ & $39.5(38.92)$ & 34.2 & 5.0 & 466.5 \\
\hline S2T1 & $95.0(77.1)$ & $66.0(54.32)$ & $38.0(38.04)$ & 20.7 & 5.5 & 659.5 \\
\hline S2T2 & $94.5(76.4)$ & 55.5 (48.14) & $41.0(39.80)$ & 28.4 & 4.9 & 629.0 \\
\hline S2T3 & $92.0(73.5)$ & $45.0(42.11)$ & $50.0(44.98)$ & 23 & 6.6 & 571.8 \\
\hline S2T4 & $90.0(71.5)$ & $40.0(39.22)$ & $40.0(39.21)$ & 21.3 & 4.8 & 614.8 \\
\hline S2T5 & $87.0(68.9)$ & $36.5(37.15)$ & $48.5(44.12)$ & 20.5 & 5.8 & 643.6 \\
\hline S2T6 & $91.0(72.6)$ & $45.5(42.4)$ & $40.5(39.51)$ & 26.6 & 5.6 & 626.5 \\
\hline S2T7 & $88.5(70.2)$ & $48.0(43.84)$ & $43.5(41.25)$ & 32.2 & 5.7 & 644.6 \\
\hline S3T1 & $94.5(76.4)$ & 30.0 (33.19) & $17.7(24.85)$ & 6.5 & 3.4 & 676.0 \\
\hline S3T2 & $92.5(74.1)$ & $29.0(32.57)$ & $15.4(23.04)$ & 11.7 & 4.8 & 601.5 \\
\hline S3T3 & $91.5(73.0)$ & $26.0(30.63)$ & $20.7(27.05)$ & 5.1 & 3.7 & 544.0 \\
\hline S3T4 & $90.0(71.6)$ & $33.0(35.04)$ & $5.3(13.23)$ & 7.8 & 4.7 & 761.2 \\
\hline S3T5 & $87.0(68.9)$ & $13.5(21.52)$ & $11.9(20.09)$ & 5 & 3.6 & 563.3 \\
\hline S3T6 & $89.5(71.1)$ & $38.5(38.34)$ & $16.7(24.06)$ & 10.5 & 4.0 & 719.5 \\
\hline S3T7 & $87.0(68.9)$ & $46.5(42.9)$ & $1.6(7.03)$ & 11.4 & 3.7 & 798.1 \\
\hline S4T1 & $83.8(66.2)$ & $13.5(21.54)$ & $6.7(14.96)$ & 2.6 & 1.9 & 575.8 \\
\hline S4T2 & $82.0(64.9)$ & $16.0(23.57)$ & $9.0(17.49)$ & 2.3 & 2.3 & 555.7 \\
\hline S4T3 & $66.0(54.3)$ & $20.0(26.53)$ & $4.5(12.24)$ & 3.3 & 2.2 & 536.6 \\
\hline S4T4 & $66.0(54.3)$ & $11.0(19.36)$ & $9.0(17.49)$ & 2.6 & 2.8 & 682.6 \\
\hline S4T5 & $62.3(52.1)$ & $4.0(11.44)$ & $19.5(26.19)$ & 0.6 & 1.6 & 443.1 \\
\hline S4T6 & $55.3(48.0)$ & $7.5(15.81)$ & $16.3(23.76)$ & 1.4 & 1.9 & 486.2 \\
\hline S4T7 & $53.0(46.7)$ & $9.0(17.45)$ & $11.1(19.40)$ & 2.2 & 2.2 & 806.9 \\
\hline S5T1 & $21.5(27.6)$ & $2.5(9.04)$ & $71.7(57.91)$ & 0.7 & 0.2 & 1.0 \\
\hline S5T2 & $20.0(26.5)$ & $3.0(9.83)$ & $25.0(29.98)$ & 0.8 & 0.7 & 17.0 \\
\hline S5T3 & $17.5(24.7)$ & $1.0(5.74)$ & 0 & 0.8 & 2.8 & 39.3 \\
\hline S5T4 & $12.0(20.2)$ & $3.0(9.33)$ & 0 & 1 & 0.5 & 82.6 \\
\hline S5T5 & $7.0(15.3)$ & $2.0(8.13)$ & 0 & 0.6 & 0.6 & 2.4 \\
\hline S5T6 & $4.0(11.4)$ & $2.0(7.85)$ & 0 & 0.6 & 0.7 & 61.2 \\
\hline S5T7 & $2.0(7.9)$ & $7.5(15.88)$ & 0 & 2.8 & 3.0 & 82.6 \\
\hline CD $(\mathrm{S} X \mathrm{~T})$ & 3.15 & 3.23 & 2.03 & 2.66 & 0.39 & 12.93 \\
\hline
\end{tabular}

